\title{
Vitamin D Intoxication, with Hypernatraemia, Potassium and Water Depletion, and Mental Depression
}

\author{
D. C. ANDERSON,* M.B., M.R.C.P., M.R.C.P.ED. ; A. F. COOPER, $\dagger$ M.B., D.P.M. ; G. J. NAYLOR, $†$ M.B., B.SC., D.P.M.
}

Brit. med. F., 1968, 4, 744-746

\begin{abstract}
Cummary : Two elderly patients suffering from manicdepressive psychosis/depressive reaction had concurrently hypercalcaemia from vitamin D intoxication. They developed hypernatraemia with severe potassium and water depletion. Hypercalcaemia was pronounced, but both patients recovered quickly and their depressive symptoms resolved following water and potassium repletion and corticosteroid therapy.
\end{abstract}

\section{Introduction}

It is easy to overlook vitamin D intoxication (Chaplin et al., 1951) unless the plasma calcium is regularly estimated in patients receiving more than a few thousand units of vitamin $D$ per day. The two cases of vitamin D intoxication reported here are of practical interest. Both patients were receiving large doses of vitamin $\mathrm{D}$ for metabolic bone disease and previously had been treated for depression. Recurrence of depressive symptoms appeared to be the initial manifestation of vitamin $D$ intoxication. The diagnosis of vitamin D intoxication was made later when both patients had marked water depletion with hypokalaemia, hypernatraemia, and azotaemia.

\section{Case 1}

A 65-year-old woman was admitted to a psychiatric hospital on 8 June 1966, following a suicidal attempt, suffering from manicdepressive psychosis-depressive reaction (I.C.D. 301.1) of two months' duration. The previous year she had attempted suicide after her husband's death and later had undergone partial gastrectomy for a duodenal ulcer. In January 1966 she developed severe back pain ; $x$-ray examination showed her bones to be thin, so calciferol 6,000 i.u. daily was prescribed for probable osteomalacia. On admission in June 1966 she weighed only $60 \frac{1}{2} \mathrm{lb}$. (27.4 kg.). Two weeks after admission amitriptyline $25 \mathrm{mg}$. t.d.s. and calcium Sandoz $3 \mathrm{~g}$. daily were prescribed, and calciferol was increased to 1.25 mg. t.d.s. (150,000 i.u. daily). Her depression lifted, she gained $20 \mathrm{lb}$. (9 kg.) in weight, and after eight weeks amitriptyline was discontinued.

Three weeks later, however, her depressive symptoms returned and she continued to deteriorate despite further treatment with amitriptyline. She complained later of weakness in the legs and difficulty in walking. An electroencephalogram was grossly abnormal, showing generalized slow activity. She refused food but continued to drink; she became polyuric, was incontinent of urine, and gradually developed severe fluid depletion and a toxic confusionai state. The electrocardiogram showed S-T depression with prominent $U$ waves. On 12 October she became deeply unconscious, with sunken eyes and marked loss of skin turgor: blood pressure was $120 / 70 \mathrm{~mm}$. $\mathrm{Hg}$ and pulse rate $76 / \mathrm{min}$. Plasma values and urine ratios before treatment are shown in the Table. Hypernatraemia and hypokalaemia were evident 14 days before vitamin $\mathrm{D}$ intoxication was diagnosed. She was treated with intravenous $5 \%$ dextrose, 4 litres in 24 hours, containing 50 milliequivalents of potassium chloride. Hydrocortisone and later prednisolone plus ampicillin and penicillin were given. Vitamin D was stopped.

- Registrar, Renal Unit, Maryfield Hospital, Dundee. Present appointment: Medical Registrar, Hammersmith Hospital and Royal Postment: Medical Registrar, Hammersmith

+ Registrar, Royal Dundee Liff Hospital, by Dundee.
Response to Treatment.-There was a dramatic improvement in her physical state within 24 hours and she rapidly regained consciousness. This coincided with a rapid fall in plasma calcium and correction of hypernatraemia and of water depletion (Fig. 1). She remained hypokalaemic for two weeks following correction of the hypercalcaemia, despite ingestion of a normal diet. Urine potassium rapidly fell to low levels. The plasma potassium level rose after oral potassium chloride was added and steroids were discontinued; plasma urea fell to normal. Eleven days after the start of treatment she was fully mobile, felt very well, and was not depressed. She remained well during two months of follow-up.

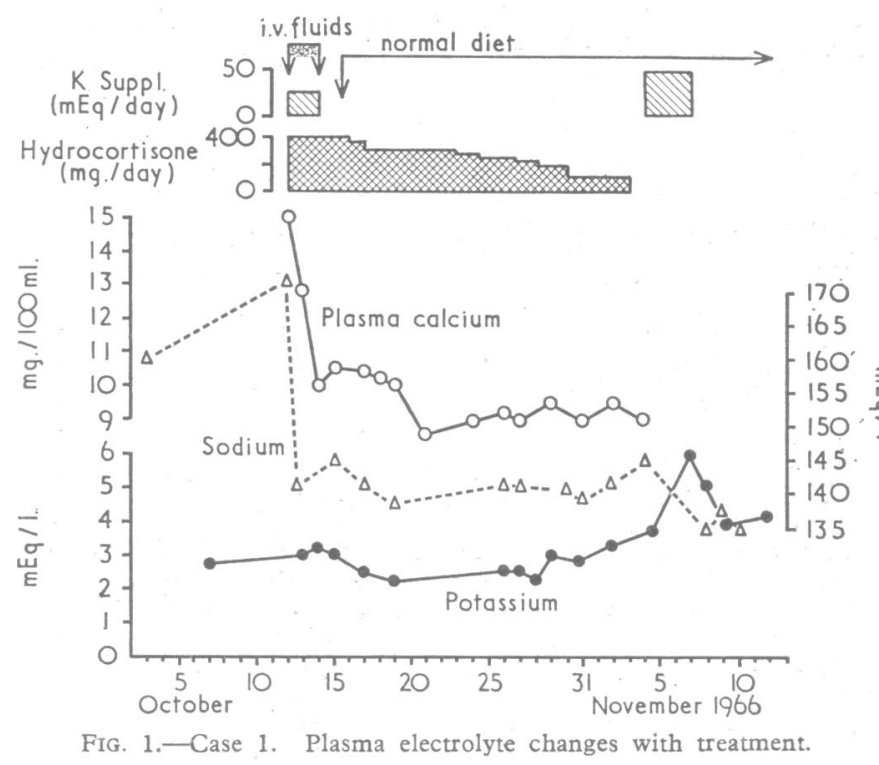

Case 2

A 73-year-old man was admitted to a psychiatric hospital in September 1966 suffering from manic-depressive psychosis/ depressive reaction (I.C.D. 301.1) in a setting of cerebral arteriosclerosis (I.C.D. 306). His medical history included partial gastrectomy for gastric ulcer in 1954, a depressive psychosis in 1961, epilepsy due to cerebral arteriosclerosis since 1963, and severe osteomalacia treated for two years with calcium gluconate $600 \mathrm{mg}$. b.d. and calciferol 100,000 i.u. daily. The calcium and calciferol were continued after his admission. Though initially he became spontaneously less depressed, he relapsed late in November and imipramine was prescribed. On 13 December imipramine was withdrawn when, following a syncopal attack, he was found to be shrunken, with dry tongue, loss of skin turgor, and a parotid abscess. His blood pressure was $128 / 75 \mathrm{~mm}$. $\mathrm{Hg}$, pulse rate $110 / \mathrm{min}$. Plasma values and urine ratios are shown in the Table. The diagnosis of vitamin $\mathrm{D}$ intoxication was first considered because these results were strikingly similar to those seen in Case 1.

$\mathrm{He}$ was treated with hydrocortisone and was given 3 litres of $5 \%$ dextrose and 1 litre of $1 / 6$ molar sodium lactate with 100 milliequivalents of potassium chloride in the first 24 hours ; ampicillin and later penicillin and streptomycin were given. Calciferol and calcium gluconate were discontinued.

Response to Treatment.-Rapid improvement in his physical state was accompanied by electrolyte changes similar to those shown by 
Plasma Values and Urine Ratios Before Treatment

\begin{tabular}{|c|c|c|c|c|c|c|c|c|c|c|c|}
\hline \multirow[b]{2}{*}{ Case No. } & \multirow[b]{2}{*}{ Date } & \multicolumn{7}{|c|}{ Plasma Urea and Electrolyte Values } & \multicolumn{3}{|c|}{ Urine Electrolyte/Creatinine Ratios } \\
\hline & & $\begin{array}{c}\text { Urea } \\
\text { (mg./100 ml.) }\end{array}$ & $\begin{array}{c}\mathrm{Na} \\
(\mathrm{mEq} / 1 .)\end{array}$ & $\underset{(\mathrm{mEq} / \mathrm{l} .)}{\mathrm{K}}$ & $\underset{(\mathrm{mEq} / \mathrm{l} .)}{\mathrm{Cl}}$ & $\underset{(\mathrm{mEq} / \mathrm{l} .)}{\mathrm{HCO}_{3}}$ & (mg./100 ml.) & 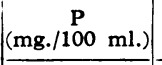 & $\begin{array}{c}\mathrm{Ca} / \mathrm{Cr}{ }^{*} \\
\text { (mg./mg.) }\end{array}$ & $\begin{array}{c}\mathrm{K} / \mathrm{Cr} \\
(\mathrm{mEq} / \mathrm{mg} .)\end{array}$ & $\begin{array}{c}\mathrm{Na} / \mathrm{Cr} \\
\text { (mEq/mg.) }\end{array}$ \\
\hline$\frac{1}{2}$ & $\begin{array}{l}12 / 10 / 66 \\
13 / 12 / 66\end{array}$ & $\begin{array}{l}216 \\
126\end{array}$ & $\begin{array}{l}174 \\
153\end{array}$ & $\begin{array}{l}3 \cdot 0 \\
2 \cdot 8\end{array}$ & $\begin{array}{l}122 \\
108\end{array}$ & $\begin{array}{l}35 \\
23\end{array}$ & $\begin{array}{l}15 \\
14 \cdot 8\end{array}$ & $\begin{array}{l}2.5 \\
3 \cdot 0\end{array}$ & $\begin{array}{l}0 \cdot 186 \\
0 \cdot 27\end{array}$ & $\begin{array}{l}0 \cdot 14 \\
0 \cdot 124\end{array}$ & $\begin{array}{l}0.03 \\
0.151\end{array}$ \\
\hline
\end{tabular}

Normal $\mathrm{Ca} / \mathrm{Cr}$ ratio $=0.03-0 \cdot 28$ ( Nordin, 1959).

Case 1 (Fig. 2), and a fall in plasma urea to normal, closely followed by disappearance of his depression and hypochondriacal delusions. He was discharged home well but still moderately demented after two months' observation.

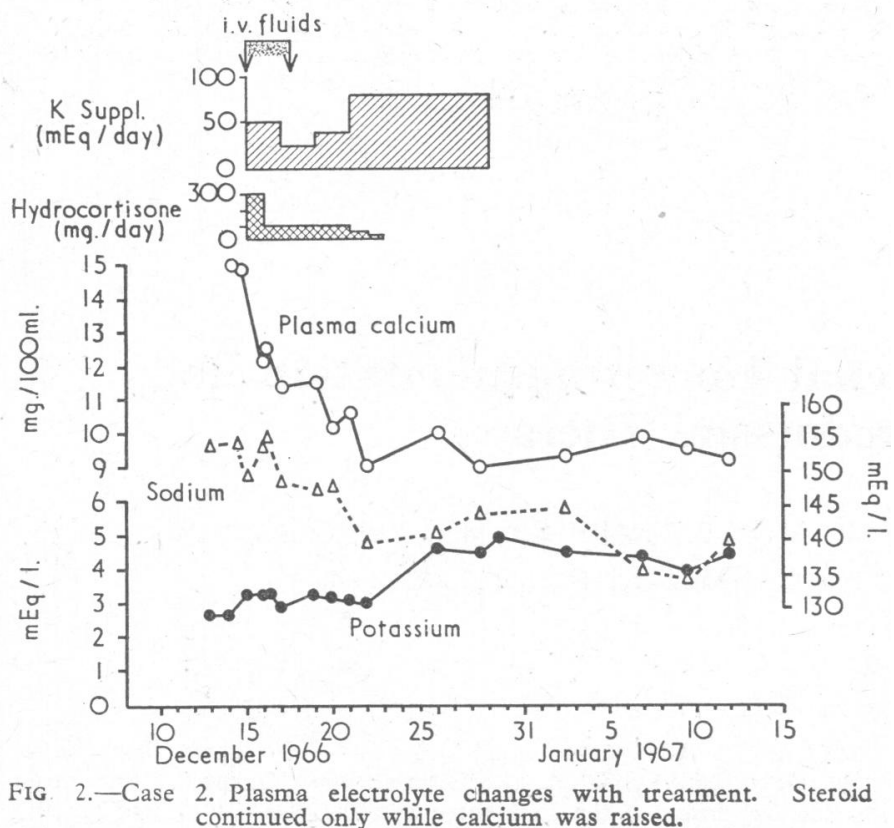

\section{Discussion}

\section{Depression}

Vitamin D intoxication may be associated with an organic mental syndrome (Lehrer and Levitt, 1960), but we have found only one previous report of its association with mental depression (Chaplin et al., 1951). Our two patients are known to have previously suffered from manic-depressive psychosis, but the return of their depressive symptoms shortly before the appearance of physical symptoms of vitamin $\mathrm{D}$ intoxication, together with the rapid improvement in their depression after treatment of the metabolic upset, suggests that vitamin D intoxication may have been important in precipitating and maintaining the depression to which they were both predisposed.

Depression has been described in hypercalcaemic states, notably in primary hyperparathyroidism (Henson, 1966-7), and is known to be a feature of potassium deficiency (Mayer-Gross et al., 1960). However, it is probably unjustifiable to speculate on the mechanism of production of depression in these two patients, since the electrolyte and metabolic changes were so profound, though in depressive illness alterations in sodium and potassium distribution (Coppen and Shaw, 1963 ; Shaw and Coppen, 1966) and calcium balance (Flach, 1964) have been reported.

\section{Electrolyte Disturbances}

Among other renal effects hypercalcaemia may lead to a state resembling diabetes insipidus that is pitressin-resistant (Cohen et al., 1957 ; Epstein, 1960 ; Gill and Bartter, 1961), and may also cause potassium depletion (Huth et al., 1959 ; Ferris et al., 1961 ; Sanderson, 1967 ; Schwartz and Relman, 1967). Our two patients had hypokalaemia and there was a relatively high urine potassium, which fell along with the plasma calcium level during recovery (Fig. 3). Potassium depletion alone causes an effect similar to that of hypercalcaemia on water excretion (Epstein, 1960); our patients therefore showed a double reason for a renal water-losing state, and when they were too ill to maintain an adequate fluid intake they became hypernatraemic.

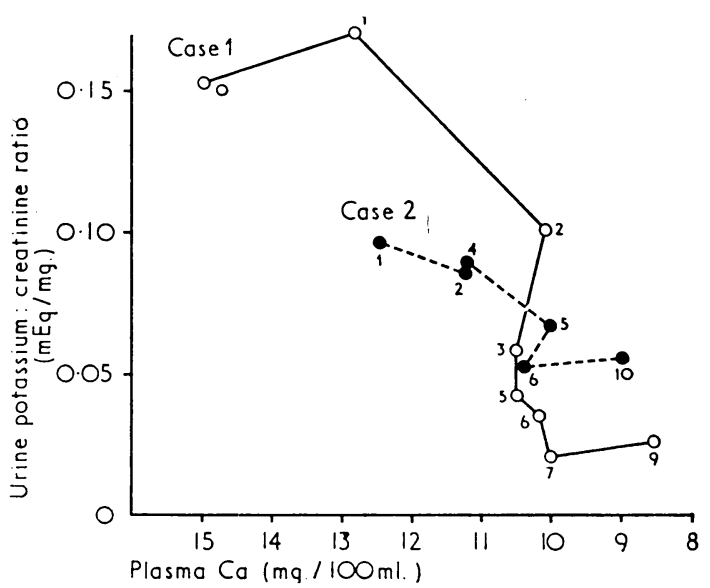

FIG. 3.-Urine potassium:creatinine ratio plotted against plasma calcium level. Continuous lines (Case 1) and dotted lines (Case 2) connect consecutive results; small numbers adjacent to points indicate number of days after start of therapy.

Hypernatraemia has only rarely been reported complicating hypercalcaemia ; two other patients with vitamin $\mathrm{D}$ intoxication had plasma sodium levels of 150 and $156 \mathrm{mEq} / 1$. (Verner et al., 1958), and Guyer (1965) reported a case of thyrotoxicosis with hypercalcaemia and vomiting who had a serum sodium of $178 \mathrm{mEq} / \mathrm{l}$. That hypernatraemia is unusual may be because hypercalcaemia can also impair the ability of the kidney to conserve sodium, at least when azotaemia has developed (Epstein, 1960); in contrast, potassium depletion may cause sodium retention (Black and Milne, 1952; Wolff et al, 1968). Our Case 2 was losing more sodium than potassium when hypercalcaemic, though Case 1 was losing very little. Clinically, the diagnosis of hypernatraemic dehydration is easily missed, since the circulation is well maintained even in advanced fluid depletion. It is worth noting in contrast that hypernatraemia from other causes is often associated with hypocalcaemia (Finberg and Harrison, 1955).

These two cases emphasize the importance of adequate water and electrolyte repletion to correct the secondary disorders caused by hypercalcaemia; short-term steroid therapy is also of importance in vitamin $\mathrm{D}$ intoxication. Other authors (Kenny and Holliday, 1964 ; Sterling and Rupp, 1967) have used isotonic sodium sulphate infusions in vitamin $\mathrm{D}$ intoxication to lower the plasma calcium, but since this treatment may itself cause hypernatraemia (Heckman and Walsh, 1967) and it increases potassium excretion (Chakmakjian and Bethune, 1966) we think that it is dangerous. Our results demonstrate that sodium sulphate and sodium phosphate infusions are not necessary in treating hypercalcaemia from this cause. 
We are grateful to Professor P. D. Griffiths and his staff for the biochemical estimations, to $\mathrm{Dr}$, W. K. Stewart for permission to publish these cases, and to Dr. P. G. Aungle and Professor I. R. C. Batchelor for their helpful comments.

Requests for reprints should be sent to Dr. D. C. Anderson.

\section{REFERENCES}

Black, D. A. K., and Milne, M. D. (1952). Clin. Sci., 11, 397 Chakmakjian, Z. H., and Bethune, J. E. (1966). New Engl. J. M.ed., 275, 862

Chaplin, H., Clark, L. D., and Ropes, M. W. (1951). Amer. 7. med. Sci.,

Cohen, S. I. I., Fitzgerald, M. G., Fourman, P., Grifiths, W. J., and de Wardener, H. E. (1957). Quart. F. Med., 26, 423.

Coppen, A., and Shaw, D. M. (1963). Brit. med. Y., 2, 1439.

Epstein, F. H. (1960). \$. chron. Dis., 11, 255 . I., 2, 14 . (1961). New Engl. Ұ. Med., 265,'924.
Finberg, L., and Harrison, H. E. (1955). Pediatrics, 16, 1.

Fitz, T. E., and Hallman, B. L. (1952). Arch. intern. Med., 89, 547.

Flach, F. F. (1964). Brit. F. Psychiat., 110, 588.

Gill, J. R., and Bartter, F. C. (1961). J. clin. Invest., 40, 716

Guyer, P. B. (1965). Brit. med. Ұ., 1 , 169.

Heckman, B. A., and Walsh, J. H. (1967). New Engl. 7. Med., 276 1082 .

Henson, R. A. (1966-7). F. roy. Coll. Phycns Lond., 1, 41. Huth, E. J., Mayock, R. L., and Kerr, R. M. (1959). Amer. F. Med.,

Kenny, F. M., and Holliday, M. A. (1964). New Engl. F. Med., 271, 708.

Lehrer, G. M., and Levitt, M. F. (1960). 7. Mt Sinai Hosp., 27, 10.

Mayer-Gross, W., Slater, E., and Roth, M. (1960). Clinical Psychiatry, 2nd ed. London.

Nordin, B. E. C. (1959). Lancet, 2, 368.

Sanderson, P. H. (1967). Brit. med. F., 1, 679.

Schwartz, W. B., and Relman, A. S. (1967). New Engl. 7. Med., 276, 452 .

Shaw, D. M., and Coppen, A. (1966). Brit. F. Psychiat., 112, 269.

Sterling, F. H., and Rupp, J. J. (1967). Acta endocr. (Kbh.), 54, 380.

Verner, J. V., Engel, F. L., and McPherson, H. T. (1958). Ann. intern. Med., 48, 765 .

Wolff, H. P., et al. (1968). Lancet, 1, 257.

\title{
Reticulum Cell Sarcoma after Renal Homotransplantation and Azathioprine and Prednisone Therapy
}

\author{
P. B. DOAK,* M.B., M.R.C.P., M.R.A.C.P. ; J. Z. MONTGOMERIE, ${ }^{*}$ M.B., M.R.A.C.P. \\ J. D. K. NORTH, $\dagger$ D.PHIL., M.R.C.P., F.R.A.C.P. ; F. SMITH, $\ddagger$ M.B., F.C.PATH. M.C.P.A.
}

Brit. med. F., 1968, 4, 746-748.

\begin{abstract}
Cummary : Two patients developed reticulum cell sarcomata after they had been treated with azathioprine and prednisone in the course of cadaveric renal transplantation. Both had terminal widespread herpes simplex virus infection.

Immunosuppressive therapy could be responsible for an increased risk of malignant lymphomata either directly or by facilitating infection with oncogenic viruses.
\end{abstract}

\section{Introduction}

Neoplasia has been postulated as a potential complication of depression of the immune system by drugs (Swanson and Schwartz, 1967). We report two cases in which reticulum cell sarcomata developed after renal homotransplantation and treatment with azathioprine and prednisone.

\section{Case 1}

The patient, a 34-year-old man with renal failure due to chronic glomerulonephritis, was started on regular haemodialysis treatment in June 1966. Bilateral nephrectomy was performed in September, and a disrupted wound left him with a large ventral hernia. In November he received two unsuccessful kidney transplants from cadavers, receiving treatment with azathioprine and prednisone for seven days. Regular haemodialysis treatment was continued until April 1967, when a third kidney was transplanted from a 38-yearold man who died of cerebral trauma. Necropsy of the donor showed no evidence of neoplasia. The kidney functioned well, and the creatinine clearance rose to $70 \mathrm{ml} . / \mathrm{min}$. within one month of transplantation. Four mild episodes of transplant rejection with temporary decline in renal function were treated with high doses of

* Physician, Medical Unit, Auckland Hospital, Auckland, New Zealand. t Professor of Medicine, University of Auckland, Auckland, New Zealand. $\ddagger$ Pathologist, Auckland Hospital, Auckland, New Zeala:ad. prednisone. Actinomycin C $400 \mu \mathrm{g}$. was also given three times. The mean daily dose of azathioprine was $75 \mathrm{mg}$. The mean prednisone dose for the first three months was $60 \mathrm{mg}$. daily, and thereafter $35 \mathrm{mg}$. daily. The ventral incisional hernia was repaired with a Teflon patch in July, but a staphylococcal infection of the wound developed and persisted until death.

In September he developed extensive herpetic lesions on the lips and inside his mouth. Candida albicans was cultured from the oral swab, and he was given local nystatin and gentian violet, followed by intravenous amphotericin (120 mg. in four days). The tongue became ulcerated, and the oral lesions extended to involve the oesophagus. He had marked cervical adenopathy, and both epitrochlear glands were enlarged.

During the final six weeks of life he also received penicillin and cloxacillin and kanamycin. Local iododeoxyuridine $1 \%$ was applied to the herpetic lesions without benefit. His general condition deteriorated steadily, though renal function remained satisfactory until he died in November 1967.

At necropsy there was severe ulceration of the skin of the lips, the right side of the face, and both eyelids. There was a large ulcer near the tip of the tongue measuring $2 \mathrm{~cm}$. across. Histological examination of the tongue showed the ulcerated surface to contain many Gram-negative bacilli, Gram-positive cocci, and small numbers of the spores and hyphae consistent with $C$. albicans. Deep to the area of ulceration and extending among the striated muscle and fat was a malignant tumour. The lower two-thirds of the oesophagus showed many deep ulcers, small numbers of Grampositive cocci, and Gram-negative bacilli, but no fungal elements were seen. In the submucosa were small numbers of cells with large nuclei, often vacuolated, containing viral inclusion bodies. In the deeper parts of the submucosa were small clumps of tumour cells.

The liver weighed $2,940 \mathrm{~g}$. When cut across it showed many tumour nodules, the largest measuring $1.5 \mathrm{~cm}$. across (Fig. 1). They were red with mottled white areas. Marked fatty degeneration was present with no increase in fibrous tissue or any bile duct proliferation. Many small necrotic areas in which liver cells had disappeared and which contained degenerating red cells were seen. Among this necrotic tissue, but also in viable liver tissue, there were malig- 